\title{
KELENGKAPAN INFORMED CONSENT TINDAKAN BEDAH MENUNJANG AKREDITASI JCI STANDAR HPK 6 PASIEN ORTHOPEDI
}

\author{
Leni Herfiyanti \\ Politeknik Piksi Ganesha Bandung \\ leni_10303105@yahoo.com
}

\begin{abstract}
Informed consent is consent given by the patient or the patient's family on the basis of description of the medical acts to be performed on the patient. For doctors informed consent can create a sense of security, and can be used self-defense against possible claims or lawsuits from patients or their families arise when unwanted. While the patient, is a tribute to the rights of the patient and can be used as an excuse lawsuit against the doctor, in case of deviations from the medical practice mean consent given medical action. In addition Informed consent is also one important indicator in the assessment of accreditation. Purpose of this study is to determine the completeness of the data on Informed Consent Orthopaedic surgery in patients at Dr Hasan Sadikin, knowing assessment JCI Accreditation Standards Assessment HPK.6 Orthopaedic patients at Dr Hasan Sadikin and determine completeness relation Informed Consent surgery with JCI Accreditation assessment Assessment Standards HPK.6. The method used in this research is descriptive method qualitative approach. The Data collection by observation, literature reviews, and interviews. Total population and sample in this study as many as 61 medical records. The results showed the biggest omissions contained in the charging Informed Consent items Prognosis explanation by $54.1 \%$, Alternatives \& Risk by 52.5\%, and complications of 50.8\%. Conclusion of the influence Completeness Implementation Completion and Informed Consent of the assessment JCI Accreditation Standards Assessment HPK.6.
\end{abstract}

Keyword: Completeness of Informed consent, JCI accreditation standards, Patient and Family Rights Assessment 6

\begin{abstract}
Abstrak
Informed consent merupakan persetujuan yang diberikan oleh pasien atau keluarga pasien atas dasar penjelasan mengenai tindak medis yang akan dilakukan terhadap pasien. Bagi dokter informed consent dapat membuat rasa aman, sekaligus dapat digunakan pembela diri terhadap kemungkinan adanya tuntutan atau gugatan dari pasien atau keluarganya apabila timbul yang tidak diinginkan. Sedangkan pasien, merupakan penghargaan terhadap hak-hak oleh pasien dan dapat digunakan sebagai alasan gugatan terhadap dokter, apabila terjadi penyimpangan praktik kedokteran dari maksud diberikannya persetujuan tindakan medis. Selain itu Informed consent juga menjadi salah satu indikator penting dalam penilaian akreditasi. Tujuan Penelitian ini yaitu untuk mengetahui kelengkapan pengisian data pada Informed Consent tindakan bedah pada pasien Orthopedi di RSUP Hasan Sadikin Bandung, mengetahui penilaian Akreditasi JCI Standar Penilaian HPK.6 pada pasien Orthopedi di RSUP Hasan Sadikin Bandung serta mengetahui kaitan kelengkapan pengisian fInformed Consent tindakan bedah dengan penilaian Akreditasi JCI Standar Penilaian HPK.6. Metode penelitian yang digunakan dalam penelitian ini yaitu metode deskriptif pendekatan kualitatif. Pengumpulan data dilakukan dengan cara observasi, tinjauan pustaka, dan wawancara. Jumlah populasi dan sampel dalam penelitian ini sebanyak 61 rekam medis. Hasil penelitian menunjukkan adanya ketidaklengkapan terbesar terdapat pada pengisian Informed Consent item penjelasan Prognosis sebesar 54,1\%, Alternatif \& Resiko sebesar 52,5\%, dan Komplikasi sebesar 50,8\%.
\end{abstract}

Kata Kunci : Kelengkapan Informed consent, Standar akreditasi JCI, Penilaian Hak Pasien dan Keluarga (HPK) 6. 


\section{PENDAHULUAN}

Informed consent adalah suatu kesepakatan/ persetujuan pasien atas upaya medis yang akan dilakukan oleh dokter terhadap dirinya, setelah pasien mendapatkan informasi dari dokter mengenai upaya medis yang dapat dilakukan untuk menolong dirinya, disertai informasi mengenai segala resiko yang mungkin terjadi. (Komalawati, 1989, 86).

Indikator informed consent yang lengkap adalah kelengkapan nama dan tanda tangan oleh dokter dan keluarga pasien. Keterangan waktu dan jenis tindakan juga tidak kalah pentingnya dalam pengisian lembar informed consent, karena hal ini dapat menjelaskan kapan dan apa tindakan medis yang dilakukan terhadap pasien. Kelengkapan isi informed consent harus memuat data yang lengkap, sehingga pasien, dokter, dan rumah sakit dapat mencegah terjadinya kasus-kasus hukum. Apalagi sekarang ini banyak terjadi Malpraktek sehingga membuat pasien merasa waswas terhadap kasus tersebut.

Tujuan Informed consent menurut Permenkes RI Nomor 290/MENKES/PER/III/2008 yaitu : 1) Memberikan perlindungan pada pasien terhadap tindakan dokter yang sebenarnya tidak diperlukan dan secara medik tidak ada dasar pembenarannya yang dilakukan tanpa sepengetahuan pasiennya.

2) Memberikan perlindungan hukum kepada dokter terhadap suatu kegagalan dan bersifat negatif, karena prosedur medik modern tidak tanpa resiko dan pada setiap tindakan medik ada melekat suatu resiko.

Untuk menunjang pelayanan kesehatan yang berkualitas serta menghasilkan informasi yang tepat dan akurat, tentunya harus didukung oleh adanya kelengkapan data pada setiap formulir rekam medis dan formulir persetujuan tindakan medis (Informed Consent). Apabila dari formulir tersebut tidak diisi dengan lengkap, maka akan mengakibatkan informasi yang ada di dalam rekam medis akan menjadi tidak tepat dan tidak akurat.

Rekam medis sangat berperan dalam mengemban mutu pelayanan medik yang diberikan oleh rumah sakit beserta staf mediknya, oleh karena rekam medis milik rumah sakit, yang harus dipelihara karena berguna bagi pasien, dokter, maupun rumah sakit itu sendiri. Rumah sakit harus mampu memberikan kepuasan dalam pelayanan kesehatan baik petugas yang sesuai dengan standar SPO (Standar Operating
Prosedure). Alat kesehatan yang memadai dan Rumah Sakit yang terakreditasi baik, dimana akreditasi rumah sakit adalah suatu pengakuan yang diberikan oleh pemerintah pada rumah sakit karena telah memenuhi standar yang di tentukan, sedangkan tujuan utamanya adalah meningkatkan mutu pelayanan Rumah Sakit.

Akreditasi pada dasarnya adalah proses menilai rumah sakit sejauh mana telah menerapkan standar, dalam akreditasi yang telah ditetapkan, perlunya kelengkapan Informed Consent sangat penting dengan menunjang akreditasi dimana telah ditetapkan dalam peraturan, dimana akreditasi adalah suatu pengakuan dari pemerintah yang diberikan kepada Rumah Sakit yang memenuhi standar yang ditetapkan (Dirjen YanMed Depkes R.1.NO.HK.00.06.3.5.00788 Tentang komisi gabungan Akreditasi Rumah Sakit).

Mengingat pentingnya Formulir Informed Consent diisi secara lengkap dan benar dalam menunjang akreditasi JCI (Joint Commission International) salah satunya adalah Standar Penilaian HPK.6, maka dipandang perlu untuk melakukan penelitian mengenai Kelengkapan Pengisian Informed Consent Tindakan Bedah Guna Menunjang Akreditasi Jci Standar (Hpk) 6 Pasien Orthopedi Di RSUP DR. Hasan Sadikin Bandung.

\section{METODE}

Metode penelitian adalah penelitian deskriptif pendekatan kuantitatif. Objek dalam penelitian ini adalah pelaksanaan pengisian informed consent. Teknik pengumpulan data yaitu Observasi, Dokumentasi data-data, Wawancara kepada dokter atau perawat dan studi pustaka. Teknik Analisis Data dilakukan dengna reduksi data yaitu peneliti merangkum hasil wawancara, melihat hasil observasi dan dokumentasi dengan bantuan lembaran checklist yang kemudian disajikan dalam bentuk tabel dan grafik serta melihat prosedur dan teori maupun regulasi mengenai kelengkapan informed consent dengan pelaksanaan. Penyajian data yang paling sering digunakan pada data kualitatif adalah narasi. Penarikan kesimpulan atau verifikasi dari awal penelitian dilakukan pengertian suatu benda - benda, mencatat pola, penjelasan, konfigurasi - konfigurasi, yang mungkin, alur sebab akibat dan proporsisi. Dari hal tersebut maka diambil suatu kesimpulan yang dapat menggambarkan keadaan objek penelitian (Miles dan Huberman, 1992). 


\section{HASIL}

\section{Pelaksanaan Informed Consent}

1. Ketentuan mengenai prosedur pengisian formulir Informed Consent sudah ada, ini terbukti dengan adanya Standar Prosedur Operasional (SPO) Informed Consent yang ditetapkan oleh RSUP Dr. Hasan Sadikin Bandung yang diterbitkan pada tanggal 13 Mei 2010 dan ditandatangani oleh Direktur Utama RSUP Dr. Hasan Sadikin Bandung. SPO ini sudah sesuai dan memenuhi ketentuan akreditasi rumah sakit. Tetapi dalam pelaksanaannya masih belum berjalan dengan baik sesuai dengan ketentuan yang ada.

2. Proses dari pelaksaan Informed Consent di RSUP Dr. Hasan Sadikin Bandung masih belum berjalan sebagaimana mestinya seperti yang tertuang dalam Standar Prosedur Operasional (SPO) Informed Consent. Hal ini terlihat dengan masih banyaknya formulir Informed Consent yang tidak terisi dengan lengkap.

3. Hasil penelitian mengenai kelengkapan pengisian formulir Informed Consent tindakan bedah, yaitu:

a. Identitas Pasien (diantaranya nama pasien, umur, jenis kelamin, alamat, no rekam medis) dan informasi identitas keluarga pasien (diantaranya nama pemberi persetujuan, umur, jenis kelamin, alamat, hubungan dengan pasien, tanggal persetujuan).

Tabel 1. Kelengkapan Pengisian Identitas Pasien

\begin{tabular}{llcccc}
\hline \multirow{2}{*}{ NO } & \multirow{2}{*}{ DATA } & \multicolumn{4}{c}{ Kelengkapan } \\
\cline { 3 - 6 } & & \multicolumn{3}{c}{ Ya } & \multicolumn{2}{c}{ Tidak } \\
\cline { 3 - 6 } & & N & $\%$ & N & $\%$ \\
\hline 1 & Nama Pasien & 61 & 100 & - & - \\
2 & Umur & 61 & 100 & - & - \\
3 & Jenis Kelamin & 58 & 95.1 & 3 & 4.9 \\
4 & Alamat & 42 & 68.8 & 19 & 31.2 \\
5 & No RM & 45 & 73.7 & 16 & 26.3 \\
\hline
\end{tabular}

Tabel 2. Kelengkapan Pengisian Identitas Keluarga Pasien (Pemberi Persetujuan)

\begin{tabular}{llcccc}
\hline & \multirow{2}{*}{ NO } & \multirow{2}{*}{ DATA } & \multicolumn{4}{c}{ Kelengkapan } \\
\cline { 3 - 6 } & & \multicolumn{3}{c}{ Ya } & \multicolumn{2}{c}{ Tidak } \\
\cline { 3 - 6 } & & $\mathbf{N}$ & $\mathbf{\%}$ & $\mathbf{N}$ & $\mathbf{\%}$ \\
\hline 1 & $\begin{array}{l}\text { Nama Pemberi } \\
\text { Persetujuan }\end{array}$ & 61 & 100 & - & - \\
2 & Umur & 55 & 90,2 & 6 & 9.8 \\
3 & Jenis Kelamin & 51 & 83.6 & 10 & 16,4 \\
\hline
\end{tabular}

\begin{tabular}{llllll}
\hline \multirow{2}{*}{ NO } & \multirow{2}{*}{ DATA } & \multicolumn{4}{c}{ Kelengkapan } \\
\cline { 3 - 6 } & & \multicolumn{2}{c}{ Ya } & \multicolumn{2}{c}{ Tidak } \\
\cline { 3 - 6 } & & $\mathbf{N}$ & $\mathbf{\%}$ & \multicolumn{1}{c}{$\mathbf{N}$} & $\mathbf{\%}$ \\
\hline 4 & Alamat & 40 & 65,6 & 21 & 34,4 \\
5 & T a n g g a 1 & 59 & 96,7 & 2 & 3,3 \\
\hline & Persetujuan & & & & \\
\hline
\end{tabular}

Tabel 3. Kelengkapan Pengisian Identitas Dokter

\begin{tabular}{cccccc}
\hline \multirow{2}{*}{ NO } & \multirow{2}{*}{ DATA } & \multicolumn{4}{c}{ Kelengkapan } \\
\cline { 3 - 6 } & & \multicolumn{2}{c}{ Ya } & \multicolumn{2}{c}{ Tidak } \\
\cline { 3 - 6 } & $\mathbf{N}$ & $\mathbf{\%}$ & $\mathbf{N}$ & $\mathbf{\%}$ \\
\hline 1 & $\begin{array}{l}\text { Dokter } \\
\text { Pelaksana } \\
\text { Tindakan }\end{array}$ & 43 & 70,5 & 18 & 29,5 \\
2 & $\begin{array}{l}\text { Pemberi } \\
\text { Informasi } \\
\text { (Jabatan) }\end{array}$ & 33 & 54,1 & 28 & 45,9 \\
\hline
\end{tabular}

b. Adanya Pelaporan Penting

Formulir yang memuat laporan penting pasien diantaranya jenis informasi yang akan diberikan

Tabel 4. Kelengkapan Pengisian Jenis Tindakan

\begin{tabular}{llccccc}
\hline \multirow{2}{*}{ NO } & \multirow{2}{*}{ DATA } & \multicolumn{4}{c}{ Kelengkapan } \\
\cline { 3 - 6 } & & \multicolumn{2}{c}{ Ya } & \multicolumn{2}{c}{ Tidak } \\
\cline { 3 - 6 } & & $\mathbf{N}$ & $\mathbf{\%}$ & N & $\%$ \\
\hline 1 & Jenis Tindakan & 61 & 100 & - & & - \\
\hline
\end{tabular}

Tabel 5. Kelengkapan Pengisian Jenis Informasi

\begin{tabular}{|c|c|c|c|c|c|}
\hline \multirow{3}{*}{ NO } & \multirow{3}{*}{ DATA } & \multicolumn{4}{|c|}{ Kelengkapan } \\
\hline & & \multicolumn{2}{|c|}{ Ya } & \multicolumn{2}{|c|}{ Tidak } \\
\hline & & $\mathbf{N}$ & $\%$ & $\mathbf{N}$ & $\%$ \\
\hline 1 & $\begin{array}{l}\text { Diagnosis } \\
\text { Kerja }\end{array}$ & 58 & 95,1 & 3 & 4,9 \\
\hline 2 & $\begin{array}{l}\text { Diagnosis } \\
\text { Banding }\end{array}$ & 33 & 54,1 & 28 & 45,9 \\
\hline 3 & $\begin{array}{l}\text { Tindakan } \\
\text { Kedokteran }\end{array}$ & 57 & 93,4 & 4 & 6,6 \\
\hline 4 & $\begin{array}{l}\text { Indikasi } \\
\text { Tindakan }\end{array}$ & 53 & 86,8 & 8 & 13,2 \\
\hline 5 & Tata Cara & 53 & 86,8 & 8 & 13,2 \\
\hline 6 & Tujuan & 52 & 85.2 & 9 & 4,8 \\
\hline 7 & $\begin{array}{l}\text { Resiko } \\
\text { Tindakan }\end{array}$ & 43 & 70,5 & 18 & 29,5 \\
\hline 8 & Komplikasi & 30 & 49,2 & 31 & 50,8 \\
\hline 9 & Prognosis & 28 & 45,9 & 33 & 54,1 \\
\hline 10 & $\begin{array}{l}\text { Alternatif \& } \\
\text { Resiko }\end{array}$ & 29 & 47,5 & 32 & 52,5 \\
\hline 11 & Lain-Lain & 31 & 50,8 & 30 & 49,2 \\
\hline
\end{tabular}


c. Autentifikasi

Yaitu formulir yang memuat informasi Autentifikasi diantaranya nama dan tanda tangan saksi yaitu dokter selaku pemberi informasi dan Pasien/keluarga pasien selaku penerima informasi dan saksi-saksi.

Tabel 6 Kelengkapan Pengisian Autentifikasi

\begin{tabular}{|c|c|c|c|c|c|}
\hline \multirow{3}{*}{ NO } & \multirow{3}{*}{ DATA } & \multicolumn{4}{|c|}{ Kelengkapan } \\
\hline & & \multicolumn{2}{|c|}{ Ya } & \multicolumn{2}{|c|}{ Tidak } \\
\hline & & $\mathbf{N}$ & $\%$ & $\mathbf{N}$ & $\%$ \\
\hline 1 & $\begin{array}{l}\mathrm{N} \text { a m a d a n } \\
\text { Tanda Tangan } \\
\text { Dokter }\end{array}$ & 56 & 91,8 & 5 & 8,2 \\
\hline 2 & $\begin{array}{l}\text { Nam a dan } \\
\text { Tanda Tangan } \\
\text { P a s i e n / } \\
\text { K e } 1 \text { u a r g a } \\
\text { Pasien }\end{array}$ & 51 & 83,6 & 10 & 16,4 \\
\hline 3 & $\begin{array}{l}\text { Nam a dan } \\
\text { Tanda Tangan } \\
\text { Saksi }\end{array}$ & 35 & 57,4 & 26 & 42,6 \\
\hline
\end{tabular}

d. Review Pencatatan

Yaitu formulir Informed Consent yang memuat Review pencatatan dimana mutu pencatatan yang dilakukan oleh petugas kesehatan dalam pendokumentasian untuk menunjang kualitas formulir Informed Consent sehingga dapat berguna dengan baik

Tabel 7 Tabel Kelengkapan Review Pencatatan

\begin{tabular}{|c|c|c|c|c|c|}
\hline \multirow{3}{*}{ NO } & \multirow{3}{*}{ DATA } & \multicolumn{4}{|c|}{ KELENGKAPAN } \\
\hline & & \multicolumn{2}{|c|}{ Ya } & \multicolumn{2}{|c|}{ Tidak } \\
\hline & & $\mathbf{N}$ & $\%$ & $\mathbf{N}$ & $\%$ \\
\hline 1 & $\begin{array}{l}\text { Identitas } \\
\text { Pasien }\end{array}$ & & & & \\
\hline $\mathrm{a}$ & Nama Pasien & 61 & 100 & - & - \\
\hline $\mathrm{b}$ & Umur & 61 & 100 & - & - \\
\hline c & $\begin{array}{l}\text { Jenis } \\
\text { Kelamin }\end{array}$ & 58 & 95.1 & 3 & 4.9 \\
\hline d & Alamat & 42 & 68.8 & 19 & 31.2 \\
\hline $\mathrm{e}$ & No RM & 45 & 73.7 & 16 & 26.3 \\
\hline 2 & $\begin{array}{l}\text { Identitas } \\
\text { Keluarga } \\
\text { Pasien }\end{array}$ & & & & \\
\hline $\mathrm{a}$ & $\begin{array}{l}\text { Nama } \\
\text { Pemberi } \\
\text { Persetujuan }\end{array}$ & 61 & 100 & - & - \\
\hline $\mathrm{b}$ & Umur & 55 & 90,2 & 6 & 9,8 \\
\hline $\mathrm{c}$ & $\begin{array}{l}\text { Jenis } \\
\text { Kelamin }\end{array}$ & 51 & 83,6 & 10 & 16,4 \\
\hline d & Alamat & 40 & 65,6 & 21 & 34,4 \\
\hline
\end{tabular}

\begin{tabular}{|c|c|c|c|c|c|}
\hline \multirow{3}{*}{ NO } & \multirow{3}{*}{ DATA } & \multicolumn{4}{|c|}{ KELENGKAPAN } \\
\hline & & \multicolumn{2}{|c|}{ Ya } & \multicolumn{2}{|c|}{ Tidak } \\
\hline & & $\mathbf{N}$ & $\%$ & $\mathbf{N}$ & $\%$ \\
\hline $\mathrm{e}$ & $\begin{array}{l}\text { Tanggal } \\
\text { Persetujuan }\end{array}$ & 59 & 96,7 & 2 & 3,3 \\
\hline 3 & $\begin{array}{l}\text { Jenis } \\
\text { Tindakan }\end{array}$ & & & & \\
\hline $\mathrm{a}$ & $\begin{array}{l}\text { Nama } \\
\text { Tindakan }\end{array}$ & 61 & 100 & - & - \\
\hline 4 & $\begin{array}{l}\text { Jenis } \\
\text { informasi }\end{array}$ & & & & \\
\hline $\mathrm{a}$ & $\begin{array}{l}\text { Diagnosa } \\
\text { Kerja }\end{array}$ & 58 & 95,1 & 3 & 4,9 \\
\hline $\mathrm{b}$ & $\begin{array}{l}\text { Diagnosa } \\
\text { Banding }\end{array}$ & 33 & 54,1 & 28 & 45,9 \\
\hline $\mathrm{c}$ & $\begin{array}{l}\text { Tindakan } \\
\text { Kedokteran }\end{array}$ & 57 & 93,4 & 4 & 6,6 \\
\hline d & $\begin{array}{l}\text { Indikasi } \\
\text { Tindakan }\end{array}$ & 33 & 86,8 & 8 & 13,2 \\
\hline $\mathrm{e}$ & Tata Cara & 53 & 86,8 & 8 & 13,2 \\
\hline $\mathrm{f}$ & Tujuan & 52 & 85,2 & 9 & 4,8 \\
\hline $\mathrm{g}$ & $\begin{array}{l}\text { Resiko } \\
\text { Tindakan }\end{array}$ & 43 & 70,5 & 18 & 29,5 \\
\hline $\mathrm{h}$ & Komplikasi & 30 & 49,2 & 31 & 50,8 \\
\hline i & Prognosis & 28 & 45.9 & 33 & 54,1 \\
\hline $\mathrm{j}$ & $\begin{array}{l}\text { Alternatif \& } \\
\text { Resiko }\end{array}$ & 29 & 47,5 & 32 & 52,5 \\
\hline 5 & Autentifikasi & & & & \\
\hline $\mathrm{a}$ & $\begin{array}{l}\text { Nama dan } \\
\text { Tanda Tangan } \\
\text { Dokter }\end{array}$ & 56 & 91,8 & 5 & 8,2 \\
\hline $\mathrm{b}$ & $\begin{array}{l}\text { Nama dan } \\
\text { Tanda Tangan } \\
\text { Pasien/ } \\
\text { Keluarga } \\
\text { Pasien }\end{array}$ & 51 & 83,6 & 10 & 16,4 \\
\hline $\mathrm{c}$ & $\begin{array}{l}\text { Nama dan } \\
\text { Tanda Tangan } \\
\text { Saksi }\end{array}$ & 35 & 57,4 & 26 & 42,6 \\
\hline
\end{tabular}

Dengan adanya ketidaklengkapan tersebut, selain berdampak pada menurunnya kualitas rekam medis juga berdampak pada penilaian Akreditasi JCI Standar HPK.6 yang membahas Informed Consent, sehingga akan berdampak pada jaminan kepastian hukum bagi pasien, tenaga rekam medis dan rumah sakit.

Indikator Informed Consent yang lengkap adalah kelengkapan nama dan tanda tangan dokter dan keluarga pasien. Kendala yang menyebabkan kelengkapan tersebut adalah merupakan kealpaan dokter, meski demikian tetap akan melemahkan posisi dokter/ rumah sakit apabila terjadi sengketa 
dikemudian hari, dimana alat bukti berupa formulir Informed Consent menjadi kurang kuat akibat tidak jelasnya identitas yang menandatangani Informed Consent dari pihak pasien maupun dokter yang menangani. Pasal-pasal yang mengatur mengenai pelanggaran pengisian Informed Consent dikenai sangsi administratif seperti terdapat pada pasal 13 PERMENKES No. 269/MENKES/PER/III/2008 tentang Informed Consent mengatur tentang sangsi administratif yang berbunyi “ Terhadap dokter yang melakukan tindakan medik tanpa persetujuan pasien atau keluarganya, dapat dikenakan sangsi administratif berupa pencabutan ijin praktek".

\section{Akreditasi JCI Standar HPK.6}

Sebagai upaya mengsukseskan Akreditasi JCI kegiatan pelayanan perlu ditentukan dalam persiapan dan rencana strategis untuk mencapai kelulusan Akreditasi, salah satu yang dinilai adalah Pelaksanaan Informed Consent dan yang dinilai adalah Standar HPK.6. Berikut adalah evaluasi dari hasil Analisis penulis :

\section{Tabel 8 Hasil Analisis Standar Penilaian HPK.6}

\begin{tabular}{|c|c|c|c|}
\hline No & $\begin{array}{l}\text { Elemen Penilaian } \\
\text { (EP) }\end{array}$ & $\begin{array}{l}\text { Memenuhi } \\
\text { Syarat }\end{array}$ & $\begin{array}{c}\text { Tidak } \\
\text { Memenuhi } \\
\text { Syarat }\end{array}$ \\
\hline 1 & $\begin{array}{l}\text { Rumah sakit telah } \\
\mathrm{m} \text { e } \mathrm{n} \text { a b a r k a n } \\
\text { dengan jelas proses } \\
\text { informed consent } \\
\text { dalam kebijakan } \\
\text { dan prosedur. }\end{array}$ & $\checkmark$ & \\
\hline 2 & $\begin{array}{l}\text { Staf yang ditunjuk } \\
\text { dilatih untuk } \\
\text { melaksanakan } \\
\text { kebijakan dan } \\
\text { prosedur tersebut. }\end{array}$ & $\checkmark$ & \\
\hline 3 & $\begin{array}{l}\text { Pasien memberikan } \\
\text { informed consent } \\
\text { sesuai dengan } \\
\text { kebijakan dan } \\
\text { prosedur. }\end{array}$ & $\checkmark$ & \\
\hline
\end{tabular}

Tabel 9 Hasil Analisis Standar Penilaian HPK.6.1

\begin{tabular}{llcc}
\hline No & $\begin{array}{c}\text { Elemen Penilaian } \\
\text { (EP) }\end{array}$ & $\begin{array}{c}\text { Memenuhi } \\
\text { Syarat }\end{array}$ & $\begin{array}{c}\text { Tidak } \\
\text { Memenuhi } \\
\text { Syarat }\end{array}$ \\
\hline $1 \quad$ & $\begin{array}{l}\text { Pasien diberikan } \\
\text { penjelasan tentang } \\
\text { kondisi mereka } \\
\text { dan rencana } \\
\text { pengobatannya dari } \\
\\
\end{array}$ & $\checkmark$ \\
& & \\
& elemen 1 s/d 11. & \\
\hline
\end{tabular}

\begin{tabular}{|c|c|c|c|}
\hline No & $\begin{array}{l}\text { Elemen Penilaian } \\
\text { (EP) }\end{array}$ & $\begin{array}{l}\text { Memenuhi } \\
\text { Syarat }\end{array}$ & $\begin{array}{c}\text { Tidak } \\
\text { Memenuhi } \\
\text { Syarat }\end{array}$ \\
\hline 2 & $\begin{array}{l}\text { Pasien mengenal } \\
\text { identitas para dokter } \\
\text { dan praktisi yang lain } \\
\text { yang bertanggung } \\
\text { jawab melayani } \\
\text { mereka }\end{array}$ & & $\checkmark$ \\
\hline 3 & $\begin{array}{l}\text { Ada proses untuk } \\
\mathrm{m} \text { e } \mathrm{n} \text { a } \mathrm{g} \text { g a p i } \\
\text { p e } \mathrm{r} \text { i n a a n } \\
\text { tambahan informasi } \\
\text { dari pasien tentang } \\
\text { tanggung jawab } \\
\text { praktisi untuk } \\
\text { pelayanannya. }\end{array}$ & $\checkmark$ & \\
\hline
\end{tabular}

Tabel 10 Hasil Analisis Standar Penilaian HPK.6.2

\begin{tabular}{|c|c|c|c|}
\hline No & $\begin{array}{c}\text { Elemen } \\
\text { Penilaian (EP) }\end{array}$ & $\begin{array}{l}\text { Memenuhi } \\
\text { Syarat }\end{array}$ & $\begin{array}{c}\text { Tidak } \\
\text { Memenuhi } \\
\text { Syarat }\end{array}$ \\
\hline 1 & $\begin{array}{l}\text { Rumah sakit } \\
\text { m e m p u n y a i } \\
\text { prosedur untuk } \\
\text { informed consent } \\
\text { yang diberikan } \\
\text { oleh orang. }\end{array}$ & $\checkmark$ & \\
\hline 2 & $\begin{array}{l}\text { Prosedur tersebut } \\
\text { sesuai dengan } \\
\text { undang-undang, } \\
\text { budaya dan adat } \\
\text { istiadat. }\end{array}$ & $\checkmark$ & \\
\hline 3 & $\begin{array}{l}\text { Orang lain selain } \\
\text { pasien yang } \\
\text { memberikan } \\
\text { persetujuandicatat } \\
\text { dalam rekam } \\
\text { medis pasien. }\end{array}$ & & $\checkmark$ \\
\hline
\end{tabular}

Tabel 11. Hasil Analisis Standar Penilaian HPK.6.3

\begin{tabular}{|c|c|c|c|}
\hline No & $\begin{array}{l}\text { Elemen Penilaian } \\
\text { (EP) }\end{array}$ & $\begin{array}{l}\text { Memenuhi } \\
\text { Syarat }\end{array}$ & $\begin{array}{c}\text { Tidak } \\
\text { Memenuhi } \\
\text { Syarat }\end{array}$ \\
\hline 1 & $\begin{array}{l}\text { P a s i e n d a n } \\
\text { keluarganya diberi } \\
\text { penjelasan tentang } \\
\text { ling k u d a r i } \\
\text { persetujuan umum, } \\
\text { apabila cara ini } \\
\text { dipakai oleh rumah } \\
\text { sakit. }\end{array}$ & $\checkmark$ & \\
\hline 2 & $\begin{array}{l}\text { Rumah sakit } \\
\text { telah menetapkan } \\
\text { b a g a i m a n a } \\
\text { persetujuan umum, } \\
\text { bila dipakai, } \\
\text { didokumentasikan } \\
\text { di dalam rekam } \\
\text { medis pasien }\end{array}$ & $\checkmark$ & \\
\hline
\end{tabular}


Tabel 12. Hasil Analisis Standar Penilaian HPK.6.4

\begin{tabular}{|c|c|c|c|}
\hline No & $\begin{array}{l}\text { Elemen Penilaian } \\
\text { (EP) }\end{array}$ & $\begin{array}{l}\text { Memenuhi } \\
\text { Syarat }\end{array}$ & $\begin{array}{c}\text { Tidak } \\
\text { Memenuhi } \\
\text { Syarat }\end{array}$ \\
\hline 1 & $\begin{array}{l}\text { P e r s e t u j u a n } \\
\text { d i p e r o } 1 \text { e h } \\
\text { sebelum prosedur } \\
\text { pembedahan atau } \\
\text { tindakan invasif }\end{array}$ & $\checkmark$ & \\
\hline 2 & $\begin{array}{l}\text { P e r s e t u j u a n } \\
\text { diperoleh sebelum } \\
\text { dilakukan anestesi } \\
\text { ( } \mathrm{t} \text { e r m a s u k } \\
\text { pembiusan sedang } \\
\text { dan dalam). }\end{array}$ & $\checkmark$ & \\
\hline 3 & $\begin{array}{l}\text { P e r s e t u j u a n } \\
\text { diperoleh sebelum } \\
\text { penggunaan darah } \\
\text { dan produk darah. }\end{array}$ & $\checkmark$ & \\
\hline 4 & $\begin{array}{l}\text { P e r s e t u j a n } \\
\text { diperoleh sebelum } \\
\text { prosedur dan } \\
\text { perawatan berisiko } \\
\text { tinggi. }\end{array}$ & $\checkmark$ & \\
\hline 5 & $\begin{array}{l}\text { Jati diri orang } \\
\text { yang memberikan } \\
\text { informasi kepada } \\
\text { p a s i e } n \text { d a n } \\
\text { keluarganya dicatat } \\
\text { dalam rekam medis } \\
\text { pasien }\end{array}$ & & $\checkmark$ \\
\hline 6 & $\begin{array}{l}\text { Persetujuan ini } \\
\text { didokumentasi kan } \\
\text { dalam rekam medis } \\
\text { pasien dengan tanda } \\
\text { tangan atau rekaman } \\
\text { dari persetujuan } \\
\text { secara lisan }\end{array}$ & & $\checkmark$ \\
\hline 5. & $\begin{array}{l}\text { Hubungan Antara } \\
\text { K e le } \mathrm{g} \mathrm{k} \text { a } \mathrm{p} \text { a } \\
\text { Pengisian Formulir } \\
\text { Informed Consent } \\
\text { Tindakan Bedah } \\
\text { dengan Penilaian } \\
\text { Akreditasi Rekam } \\
\text { Medis JCI Standar } \\
\text { Penilaian HPK.6 }\end{array}$ & & $\checkmark$ \\
\hline
\end{tabular}

Untuk menunjang pelayanan kesehatan yang berkualitas serta menghasilkan informasi yang tepat dan akurat, tentunya harus didukung oleh adanya kelengkapan data pada setiap formulir rekam medis dan formulir persetujuan tindakan medis (Informed Consent). Apabila dari formulir tersebut tidak terisi dengan lengkap, maka akan mengakibatkan infomasi yang ada didalam Rekam Medis akan menjadi tidak tepat dan tidak akurat serta akan menurunnya kualitas Rekam Medis tersebut.

Akreditasi pada dasarnya adalah proses menilai rumah sakit sejauh mana telah menetapkan Standar, dalam akreditasi JCI yang telah ditetapkan, perlunya kelengkapan Informed Consent yang sangat penting demi menunjang Penilaian Standar HPK.6 yang telah ditetapkan. Menurut Permenkes No. 269/MenKes/Per/III/2008 Bab III Tentang Tatacara Penyelanggaraan Rekam Medis Pasal 5 Ayat (4) bahwa "Setiap pencatatan kedalam rekam medis harus dibubuhi nama, waktu, dan tandatangan dokter, dokter gigi atau tenaga kesehatan tertentu yang memberikan pelayanan secara langsung" dan hal ini akan berpengaruh pada proses penilaian Akreditasi JCI Penilaian Standar HPK.6.

\section{PEMBAHASAN}

Permasalahan yang terdapat pada pengisian formulir Informed Consent di Rumah Sakit Hasan Sadikin Bandung adalah 1) masih terdapat formulir yang tidak diisi dengan lengkap, khususnya formulir Informed Consent tindakan bedah pada pasien Ortopedi. Dapat dilihat dari tabel 3.7 perhitungan kelengkapan pengisian formulir Informed Consent tindakan Bedah. Dengan adanya kelengkapan tersebut, selain berdampak pada menurunnya kualitas rekam medis, hal ini berpengaruh pada proses penilaian Akreditasi JCI Standar HPK.6 dan terutama juga berdampak pada jaminan kepastian hukum bagi pasien, tenaga rekam medis dan rumah sakit. Indikator Informed Consent yang lengkap adalah kelengkapan nama dan tanda tangan dokter dan keluarga pasien. Kendala yang menyebabkan kelengkapan tersebut adalah merupakan kealpaan dokter, meski demikian tetap akan melemahkan posisi dokter/ rumah sakit apabila terjadi sengketa dikemudian hari, dimana alat bukti berupa formulir Informed Consent menjadi kurang kuat akibat tidak jelasnya identitas yang menandatangani Informed Consent dari pihak pasien maupun dokter yang menangani. Pasal-pasal yang mengatur mengenai pelanggaran pengisian Informed Consent dikenai sangsi administratif seperti terdapat pada pasal 13 PERMENKES No. 269/MENKES/PER/III/2008 tentang Informed Consent mengatur tentang sangsi administratif yang berbunyi " Terhadap dokter yang melakukan tindakan medik tanpa persetujuan pasien atau keluarganya, dapat dikenakan sangsi administratif berupa pencabutan ijin praktek"; 2) terdapat berkas rekam medis yang tidak kembli tepat waktu sesuai yang telah diterapkan; 3) Tidak adanya 
sosialisasi cara pengisian formulir Informed Consent terutama formulir persetujuan tindakan bedah yang benar dan pentingnya Informed Consent sebelum melakukan sebuah tindakan yang akan diberikan terhadap pasien, sehingga berdampak pada aspek hukum kesehatan yang berlaku di indonesia. Hal ini akan sangat mempengaruhi terhadap penilaian Akreditasi JCI Standar HPK.6 yaitu terpenuhinya semua Elemen Penilaian yang teraplikasikan pada formulir Informed Consent. Untuk mendapatkan Akreditasi JCI salah satunya adalah dengan terpenuhinya Standar HPK.6.

\section{Pemecahan Masalah}

1) Diadakannya sosialisasi/pertemuan secara rutin dan terjadwal kepada Perwakilan masing-masing dari UPF Kedokteran, Bidang Keperawatan dan Petugas Rekam Medis yang di selenggarakan oleh Komite Medik terkait yang berhubungan dengan pengisian dan pentingnya formulir Informed Consent ; 2) dilakukan analisis kelengkapan pada formulir Informed Consent serta dibuat aturan yang baku dengan menyediakan lembaran checklist kelengkapan; 3) petugas yang diberi delegasi oleh dokter lebih proaktif dalam mengisi formulir Informed Consent secara lengkap sesuai dengan aturan yang ada; 4) Memberi sanksi bagi petugas yang mengisi rekam medis dengan tidak lengkap dan tidak benar, seperti : memberikan teguran, memberikan surat peringatan dari Kepala Unit Rekam Medis, Diberikan sanksi sesuai dengan hukum kesehatan dan kode etik profesi.

\section{SIMPULAN}

1. Ketentuan/prosedur mengenai pengisian Informed Consent Di RSUP Dr. Hasan Sadikin Bandung sudah ada, ini terbukti dengan adanya Standar Prosedur Opersional (SPO) Informed Consent yang. Namun pelaksanaan pengisian formulir Informed Consent belum berjalan sebagaimana mestinya, hal ini dikarenakan masih terdapat formulir yang belum lengkap terutama tandatangan dan nama dokter dalam suatu persetujuan tindakan kedokteran/medis, pentingnya tanda tangan dokter dapat dijadikan sebagai alat bukti hukum yang sah bahwa dokter telah memberikan informasi dan penjelasan kepada pasien dan/atau keluarga pasien sebelum dilakukannya suatu tindakan. Selain itu juga dapat digunakan sebagai bukti dari sudut faktual yaitu dengan adanya tanda tangan dari pasien dan dokter, setidak-tidaknya dapat dipergunakan sebagai bukti pembelaan (legal defence) bahwa mereka pernah berada diruang yang sama pada waktu itu.

2. Dalam hal kelengkapan pengisian formulir Informed Consent masih terdapat formulir yang tidak terisi dengan lengkap, hal ini dibuktikan dengan adanya ketidaklengkapan pengisian formulir Informed Consent yang tinggi terdapat pada point Jenis Informasi yaitu item penjelasan Prognosis sebesar 54,1\%, Alternatif \& Resiko sebesar 52,5\%, dan Komplikasi sebesar 50,8\%. Sedangkan ketidaklengkapan terbanyak pada point Identitas pasien yaitu item Alamat sebesar $31.2 \%$, ketidaklengkapan terbanyak pada Identitas Keluarga Pasien pada item Alamat $34,4 \%$, untuk ketidaklengkapan terbanyak pada point identitas pemberi informasi yaitu pada jabatan dokter yang memberi informasi sebesar 45.9\%, ketidaklengkapan terbanyak pada point Autentifikasi pada item Nama dan Tanda Tangan Saksi sebesar 42,6\%. Kelengkapan Pengisian dan Pelaksanaan Informed Consent akan berpengaruh terhadap penilaian pada saat dilaksanakan proses akreditasi rumah sakit terutama Akreditasi JCI Standar Penilaian HPK.6 yaitu Elemen Penilaian yang harus terpenuhi sebagai penilaian apakah sudah berstandar atau belum

\section{DAFTAR PUSTAKA}

Guwandi, J.SH. Fungsi Informed Consent. Universitas Indonesia : Jakarta

Hatta, G. 2004. Pedoman Managemen Informasi Kesehatan di Sarana Pelayanan Kesehatan. Jakarta: Universitas Indonesia

Huffman, E. K. 1999. Health Information Managenent Edited By Jennifer Cofer Part II Of Translation ByErkadiur, Apikes Dharma Lanbaw: Padang.

Indriyanti, D. A. 2008. Etika dan Hukum Kesehatan,:Yogyakarta

International Principles for Healthcare Standards, A Framework of 1) requirement for standards, 3rd edition December 2007 Joint Commission International Accreditation Standards for Hospitals 4rd edition dari JCI 2011 
Jurnal Manajemen Informasi Kesehatan Indonesia Vol. 3 No.2 Oktober 2015

ISSN: 2337-6007 (online); 2337-585X (Printed)

Kamus Besar Bahasa Indonesia. 1995. Pengertian Rekam Medis

Komalawati, V. 2002.Peranan Informed consent dalam Transaksi Terapeutik. Bandung: Citra Aditya Bakti:

Munir, F. 2005. Sumpah Hipocrates : Aspek Hukum Malpraktek Dokter. Bandung: PT.Citra Aditya Bakti
Notoatmojo. 2002. Metodologi Penelitian Kesehatan. Jakarta: Rineka Cipta

Rustiyanto, E. 2009. Etika Profesi Perekam Medis \& InformasiKesehatan. Yogyakarta: Graha Ilmu

Sugiyono. 2010. Metodologi Penelitian Kuantitatif $R \& D$. Bandung: Alfabeta 